\title{
POLA PEMBELAJARAN KOOPERATIF MODEL JIGSAW BAGI SISWA SEKOLAH
}

\author{
Oleh : Didik Rinan Sumekto
}

\begin{abstract}
Cooperative learning covers either academic assignments or social goals. The important aspects of cooperative learning herewith are to assist students in developing the cooperative behaviors by implementing a good relationship among them mutually to any subject matters mastery they are learning for. The complex learning assignments, such as solving the problems, adopting critical thinking, analyzing the matters, and learning the concepts are applicably needed to the cooperative learning concept. Cooperative learning reflects views in which students may learn it from their own active participation and empirical experience through the small groups. These activities will help students to learn the social skills accordingly, besides they may mutually develop democratic behaviors, logical thinking skills, and creative quality improvements as well.

The jigsaw model cooperative learning adopts some students' potencies to interact with each other. This learning model is intended to stimulate the cooperative capability in critical and analytical thinking and to assist students who have insufficient understanding to any subject matters. The heterogenic participants (race, religion, social and economic strata, learners'capability, etc.) of the jigsaw learning model are chosen randomly. The randomly group members determination will benefit to students, because they are able to fit their selfadaptability as well as this condition is fair-regarded. The teacher's role in the jigsaw model is as a facilitator, skills trainer, controller to the learning process, motivator to students' mutual responsibility and evaluator to the multiple perspectives on the subject matters given.
\end{abstract}

Key words: Active learning, higher-order thinking skills, teacher-student and student-student interaction.

\section{PENDAHULUAN}

Undang-undang Nomor 20 Tahun 2003, pasal 3 menjelaskan bahwa pendidikan nasional berfungsi mengembangkan kemampuan dan membentuk watak serta peradaban bangsa yang bermartabat dalam rangka mencerdaskan kehidupan bangsa yang bertujuan mengembangkan potensi peserta didik melalui upaya sadar terencana untuk mewujudkan kondisi belajar dan proses pembelajaran agar peserta didik aktif dan menjadi manusia yang beriman dan bertakwa kepada Tuhan Yang Maha Esa, berakhlak mulia, sehat, berilmu, cakap, kreatif, mandiri, dan menjadi warga negara yang demokratis serta bertanggung jawab. Namun demikian, salah satu permasalahan pendidikan yang sampai saat ini masih dihadapi oleh bangsa Indonesia adalah rendahnya mutu pembelajaran, baik itu yang berkenaan dengan proses dan evaluasinya di setiap jenjang satuan pendidikan, khususnya pendidikan dasar dan menengah. Para kepala sekolah, guru, dan pemangku kebijakan pendidikan (stakeholders) terus berupaya meningkatkan mutu pendidikan, misalnya melalui

Didik Rinan Sumekto : adalah dosen Progdi Pend. Bahasa Inggris, Fakultas Keguruan dan Ilmu Pendidikan, UNWIDHA Klaten 
perbaikan dan pengembangan kurikulum nasional maupun lokal, peningkatan kompetensi guru melalui pelatihan, peningkatan kesejahteraan bagi guru, pengadaan buku dan alat-alat pelajaran, pengadaan dan perbaikan sarana dan prasarana pendidikan, dan peningkatan mutu manajemen sekolah.

Di lingkup satuan pendidikan atau sekolah, guru memiliki peran yang sangat penting dalam pelaksanaan proses pembelajaran. Sebagai guru, selain harus memiliki, mengembangkan, dan menguasai ilmu yang diajarkan, guru dituntut untuk mampu mengelola program pembelajaran, mengelola manajemen kelas, dan memilih metode pembelajaran yang sesuai dan berwawasan jauh ke depan (visioner) demi capaian mutu dan hasil belajar siswa yang baik.

Elias dan Freire (1994) menjelaskan bahwa model pembelajaran pasif merupakan pembelajaran model konservatif yang memposisikan pihak-pihak yang terlibat dalam proses pembelajaran sebagai berikut: guru menerangkan-murid mendengarkan, guru mendikte-murid mencatat, guru bertanya-murid menjawab, dan seterusnya. Kondisi pembelajaran seperti ini tak ubahnya seperti sistem pendidikan model "gaya bank", di mana pendidikan "model deposito" dijalankan. Sistem pendidikan seperti ini, peran guru sebagai deposan yang mendepositokan pengetahuan dengan berbagai pengalamannya kepada siswa, sedangkan siswa hanya menerima, mencatat dan menyimpan rapi (good documentation) semua materi yang telah disampaikan guru.

Elias dan Freire pun berkesimpulan bahwa pembelajaran model seperti ini merupakan salah satu bentuk penindasan terhadap para pembelajar, karena model ini akan menghambat proses kreativitas dan pengembangan potensi mereka dalam proses pembelajaran. Mosston (1972) memberikan penekanan pula bahwa pembelajaran model gaya komando telah memberikan sebuah "monopoli" proses pembelajaran kepada guru, di mana guru merencanakan, mengubah perilaku dan/atau materi sesuai pelajaran baru selama proses pembelajaran yang harus diterima oleh siswa, sebaliknya siswa tidak terlibat dalam proses analisis untuk menerapkan pengalaman baru mereka pada konteks kehidupan nyata dan tidak akan terlibat dalam pembahasan feedback bagi guru. Pembelajaran model gaya komando ini disikapi sebagai salah satu bentuk akhir polarisasi aliran behaviorism yang dikritik oleh para pakar pendidikan sebagai sebuah sistem pembelajaran yang mematikan semangat demokratisasi dan kreativitas siswa.

Selanjutnya pada perkembangan pembelajaran awal abad ke-20, mulai dikembangkan model pembelajaran kooperatif yang menekankan pada aktivitas siswa dan difasilitasi oleh guru sebagai sebuah sistem pembelajaran untuk mendorong perwujudan pendidikan yang demokratis. Paradigma dalam model pembelajaran kooperatif ini menitikberatkan pada seberapa besar guru memberi kesempatan kepada siswa untuk belajar dan memperoleh segala sesuatu yang diharapkan siswa dalam proses pembelajaran, dan bukan seberapa banyak ilmu yang telah disampaikan oleh guru kepada siswa. Model pembelajaran ini bersifat interaktif yang dikembangkan atas keterbukaan dari masing-masing siswa dan guru, di mana dalam proses yang membelajarkan siswa, guru dianggap sebagai pembelajar senior yang harus membimbing siswa yuniornya agar mereka memperoleh berbagai kompetensi yang lebih baik dari waktu ke waktu (Dede Rosyada, 2007). Dengan demikian, tidak ada kondisi dari masing-masing pihak yang akan mendominasi proses pembelajaran yang tengah berlangsung, karena para siswa dan guru yang dijadikan sebagai siswa senior saling memperhatikan kebutuhan belajar dan memecahkan permasalahan yang ada secara bersama-sama. 
Pembelajaran kooperatif dimaknai sebagai cara belajar bersama, saling membantu satu sama lain, dan para pembelajar telah menyepakati tujuan atau kompetensi yang akan dicapai, masing-masing individual memiliki akuntabilitas individual, dan masing-masing anggota kelompok belajar harus mempunyai kesempatan yang sama untuk mencapai keberhasilan belajar demi mencapai kompetensi ideal (Kauchak dan Eggen, 1998). Dalam pelaksanaan pembelajaran kooperatif, menurut Dede Rosyada (2007) perlu dikembangkan tujuan kelompok yang menuntut kesamaan harapan, strategi, dan kebersamaan dalam pencapaian target penguasaan kompetensi dalam mastery learning. Pada prinsipnya, dalam pembelajaran kooperatif menekankan adanya akuntabilitas setiap anggota kelompok yang bertanggung jawab untuk menguasai semua materi ajar yang dipelajari dan siap diuji dengan harapan penguasaan materi minimal $80 \%$. Apabila ada anggota kelompok belajar yang tidak paham terhadap materi yang sedang dipelajari, maka ia dapat bertanya kepada teman di kelompoknya dan salah satu dari anggota kelompok tersebut harus ada yang siap menjadi tutor atau guru sebaya. Dengan demikian, setiap anggota kelompok memiliki peluang yang sama untuk berhasil. Konsep pembelajaran kooperatif tidak mengenal istilah siswa yang lebih pandai dalam kelompoknya, karena mereka tidak dirancang untuk saling berkompetisi, tetapi mereka berkompetisi dengan hari yang telah mereka lalui dalam proses pembelajaran. Artinya, anggota kelompok yang lebih cepat dalam memahami materi ajar (fast learners) akan membantu anggota kelompok lainnya yang mengalami kesulitan dalam pemahaman materi ajar sampai mereka mencapai kompetensi yang sama.

Penerapan aktivitas belajar dengan kelompok kecil melalui pembelajaran kooperatif memiliki sejumlah keuntungan dibanding dengan penerapannya secara individual. Satu keuntungan yang memberikan kontribusi terhadap pembelajaran kooperatif ini adalah mengembangkan kemampuan sosial siswa. Berkolaborasi dengan siswa lainnya akan membantu mereka mengembangkan kemampuan berempati dengan memberikan kesempatan mereka menyikapi gagasan peserta didik lainnya dalam kelompok, di mana akan mampu memberikan kesadaran bahwa setiap siswa memiliki kekuatan dan kelemahan. Upaya yang dilakukan adalah dengan menemukan solusi terhadap masalah yang ada dalam kelompok tersebut, di samping mengembangkan kemampuan kebutuhan mengakomodasi pemikiran dan pandangan para siswa lainnya (Muijs dan Reynolds, 2005).

Namun permasalahan yang masih sering dialami adalah proses manajemen pembelajaran di sekolah selama ini belum mampu meningkatkan mutu hasil belajar sesuai dengan yang diharapkan, terlebih kalau hasil belajar tersebut dikaitkan dengan masalah penguasaan siswa terhadap materi pelajaran. Pada umumnya siswa akan merasa kesulitan dalam memahami konsep akademik secara utuh, terutama pada mata pelajaran yang sedang mereka hadapi di dalam maupun di luar kelas. Permasalahan yang dihadapi siswa ini akan berpotensi menjadi besar apabila konsep materi yang disajikan melalui cara yang monoton, sehingga akan menimbulkan kebosanan pada diri siswa dalam proses pembelajaran.

Pembahasan masalah ini akan memfokuskan pada rencana pembelajaran, terdiri atas subkomponen penyiapan program dan penetapan kebutuhan alat dan materi ajar, pengelolahan sumberdaya pendukung, yang melibatkan subkomponen ketenagaan, kelengkapan fasilitas, kelengkapan buku pelajaran dan lembar kerja siswa, kelengkapan alat bantu pelajaran, dan kelengkapan alat peraga, dan pengelolaan proses pembelajaran, yang meliputi subkomponen kualitas pengorganisasian kelas, pengerjaan tugas atau quiz 
oleh siswa, penilaian hasil tugas dan tes, yang kesemuanya merupakan bagian dari manajemen pembelajaan kooperatif model jigsaw. Penerapan model jigsaw ini memiliki pertimbangan karena satuan pendidikan diharapkan mau dan mampu menerapkan serta meningkatkan kualitas hasil belajar di masa mendatang melalui metode model belajar secara berkelompok dengan anggota 4-5 siswa yang terdiri dari kelompok asal dan kelompok ahli.

\section{PENGERTIAN BELAJAR}

Slavin (1997) mengungkapkan tentang pengertian belajar sebagai proses perubahan dalam diri seorang individu (siswa) yang disebabkan oleh pengalaman. Namun perubahan tersebut tentunya berbeda dengan berubahnya sesuatu dari semula yang bersifat pendek menjadi lebih tinggi. Berubahnya sesuatu dari pendek menjadi lebih tinggi bukan disebabkan oleh pengalaman semata, tetapi dikarenakan adanya perkembangan. Sementara itu Babbage, Byers dan Redding (2000) mengemukakan bahwa “... belajar dilihat sebagai proses aktif dan pembelajar yang berhasil sanggup menguasai suatu ketrampilan dalam suatu periode waktu dan menggunakan secara fleksibel dalam situasi yang bervariasi”. Klein (2002) menjelaskan pula bahwa “... belajar dapat diartikan sebagai sebuah hasil proses pengalaman yang menghasilkan suatu perubahan sikap yang relatif tetap, yang tidak dapat diterangkan oleh keadaan sementara, kedewasaan seseorang, atau kecenderungan respon yang kurang menjadi perhatian. Dari pendapat-pendapat tersebut, menjelaskan bahwa belajar merupakan proses pengalaman yang dilakukan seseorang sampai batas waktu tertentu untuk mendapatkan pengetahuan atau kertrampilan yang diharapkan agar dapat digunakan dalam situasi yang berbeda-beda.
Dikaitkan dengan gaya belajar, menurut Babbage, Byers dan Redding (2000), gaya belajar secara umum dimaknai sebagai "cara belajar yang lebih disukai individu". Bahwa kegiatan belajar seseorang dapat dilakukan melalui beraneka ragam metode. Belajar sebagai masalah setiap individu, hampir semua pengetahuan, ketrampilan, kebiasaan, nilai, sikap, perilaku dan semua perbuatan manusia terbentuk, mampu menyesuaikan dengan keadaan dan berkembang karena proses belajar. Belajar dapat diartikan oleh siapa saja sebagai sebuah proses yang diperoleh dari pengalaman pribadi, bukan pengalaman yang didapat orang lain. Terkait dengan faktor yang dapat mempengaruhi proses belajar, Cecep E. Rustana (2001) mengungkapkan bahwa “... salah satu faktor yang sangat mempengaruhi proses belajar adalah apa yang telah diketahui peserta didik". Menurut definisi Sumadi Suryabrata (1989) bahwa “... belajar ditunjukkan melalui suatu perubahan dalam perilaku sebagai hasil pengalaman". Untuk mendapatkan pengalaman dari apa yang telah dipelajari tersebut, tentunya selain perlu terlibat langsung, juga tidak terlepas dari peran panca indera. Pembelajar secara langsung melakukan apa yang sedang dipelajari. Sebagai contoh, seorang siswa yang belajar membaca, tanpa secara langsung anak tersebut berlatih mengucapkan huruf abjad atau kata, mengeja dan membaca dengan kemampuannya sendiri. Proses belajar tersebut akan memerlukan waktu lama, meskipun tergantung dari upaya dan kemampuan si siswa untuk mampu melakukannya dan tentunya selalu ada hambatan atau masalah untuk memperoleh keterampilan dari belajar sebagai hasil pengalamannya.

Agar benar-benar mengerti dan dapat menerapkan ilmu pengetahuan, belajar bukan sekedar mengingat, belajar harus bekerja untuk memecahkan masalah, menemukan sesuatu untuk dirinya dan selalu bergulat dengan berbagai gagasan yang dimiliki. Guru 
tidak hanya sekedar menuangkan sejumlah informasi, tetapi harus berupaya agar konsep-konsep penting dapat diterima dan bertahan lebih lama dibenak siswa selama proses pembelajaran tersebut dilakukan. Dalam penyelenggaraan pendidikan di sekolah, pada dasarnya menciptakan kondisi agar seorang siswa dapat belajar untuk mendapatkan pengetahuan yang berguna menjadi prioritas utama. Pannen, Dina Mustafa, dan Mustika Sekarwinahyu (2001) menekankan bahwa belajar sebagai proses mengasimilasi dan menghubungkan pengalaman atau informasi yang dipelajari dengan pengetahuan yang sudah dimiliki siswa sehingga pengetahuan mereka dapat berkembang. Belajar bukan suatu proses menerima informasi secara pasif belaka tetapi dengan menyimpannya sebagai hasil dari latihan berulang kali sebagai upaya penguatan. Dalam belajar siswa harus aktif menghubungkan tugas-tugas atau materi baru dengan pengetahuan yang telah dimiliki, mengasimilasi informasi baru tersebut dan mengkonstruksi pengertian mereka sendiri (Ratumanan, 2003).

Permasalahan belajar perlu direncanakan secara cermat dan bermakna, hal ini diperlukan untuk mengembangkan rasa ingin tahu pada setiap siswa. Rasa ingin tahu tersebut merupakan dorongan untuk membangun tampilan dalam otak, tentang apa yang mereka hayati. Pada saat mereka tumbuh semakin dewasa, perkembangan rasa ingin tahu akan semakin luas dan abstrak. Oleh karena itu, dalam belajar siswa harus tahu makna belajar dan menggunakan pengetahuan dan ketrampilan yang diperolehnya untuk memecahkan masalah dalam kehidupan. Sehubungan dengan pehamanan tersebut, Cony, Putrawan dan Setiawan (1988) menjelaskan bahwa “... manusia sebagai makhluk yang berpikir, mempunyai potensi kreatif, mampu berimajinasi dengan cara belajar, dan mengembangkan gagasan dan kemampuannya sampai sekarang”. Atas penjelasan tersebut, tercermin bahwa ada potensi kreatif yang kuat pada diri setiap siswa. Dengan memiliki kreativitas, seorang siswa akan dapat memperoleh berbagai kemajuan, baik kemajuan dalam pemahaman suatu pengetahuan, kemajuan penguasaan pada suatu ketrampilan, kemajuan dalam bidang usaha dan sebagainya termasuk juga dalam bidang peningkatan kualitas belajar. Potensi kreatif yang acapkali disebut, merupakan motivasi untuk berprestasi. Istilah motivasi yang sering terdengar, diartikan sebagai dorongan pihak yang belajar.

Belajar diartikan sebagai proses seorang siswa untuk mendapatkan pengalaman, sedangkan pembelajaran adalah cara belajar yang dalam prosesnya memerlukan keterlibatan guru, orang tua, metode, media, infrastruktur dan sebagainya. Oleh karena itu, upaya berprestasi dalam belajar tidak mungkin terlepas dari masalah lingkungan untuk mendukung terciptanya suasana belajar yang menyenangkan dan bermakna. Lingkungan belajar yang tidak kondusif, dipastikan akan sangat sulit untuk menghasilkan prestasi belajar yang maksimal, terlebih kalau tingkat keberhasilan tersebut dikaitkan dengan masalah penguasaan materi pelajaran yang telah dipelajari siswa.

\section{LINGKUNGAN BELAJAR}

Kualitas belajar siswa dapat saja dipengaruhi oleh faktor lingkungan. Terciptanya lingkungan untuk belajar, baik belajar tentang kehidupan nyata atau mengkaji masalah-masalah sosial dan pribadi, akan memungkinkan seseorang tahan belajar. Menurut Reiger dan Stang (2000), “... teachers need to be curious, imaginative, empathetic, interesting, friendly and hard working in order to be effective in the classroom. Thereby, creating a learning environment 
that enhances and strengthens the learning deposition of student.” Artinya, “... guru perlu mengetahui, memiliki daya imaginasi, tegas, pemerhati, ramah dan pekerja keras agar ditaati di dalam kelas. Pendapat tersebut menunjukkan bahwa masalah lingkungan belajar, berpengaruh kuat terhadap kebutuhan siswa untuk belajar.

Menurut Soeparman Kardi dan Muhammad Nur (2000) suatu lingkungan belajar yang kondusif mengkomunikasikan pentingnya belajar, membantu menyesuaikan siswa menjadi pembelajar dengan pengendalian diri sendiri. Terciptanya lingkungan yang layak, misalnya jauh dari kebisingan, bersih, alami, aman, tertib, asri, dan nyaman, akan mendorong terjadinya proses pembelajaran dengan baik. Selain itu, lingkungan yang demikian akan membuat siswa merasa tahan untuk belajar. Hal tersebut itulah yang sebenarnya merupakan kebutuhan mendasar dalam belajar. Pentingnya lingkungan belajar, menurut Nurhadi (2002), adalah dengan mengurangi model belajar yang selama ini sudah menjadi tradisi atau kultur, seperti guru beraksi di panggung, siswa menonton dan selayaknya diganti menjadi siswa aktif bekerja dan belajar di panggung, guru mengarahkan dari dekat. Lingkungan belajar untuk pola pembelajaran kooperatif, dicirikan oleh proses demokrasi dan peran aktif siswa dalam menentukan apa yang harus dipelajari dan bagaimana mempelajari. Jika ingin berhasil dalam pola pembelajaran kooperatif, materi pelajaran secara lengkap harus telah tersedia di ruang guru, di perpustakaan atau di pusat media. Tingkat keberhasilan juga menghendaki syarat menjauhkan dari "kesalahan tradisional", yaitu mengelola atau mengatur perilaku siswa dalam kerja kelompok. Struktur dalam pembentukan kelompok dan pendefinisian semua prosedur belajar dilakukan oleh guru, namun siswa diberi kebebasan dalam mengendalikan kekompakan dan keutuhan belajar dari waktu ke waktu. Belajar efektif harus dimulai dari lingkungan belajar yang berpusat pada siswa (student learning-centered). Oleh karena itu pengkondisian lingkungan belajar yang berpusat pada siswa akan menyenangkan dan bermakna, hal tersebut dapat dipastikan akan mendukung terciptanya proses belajar secara optimal.

\section{PEMBELAJARAN KOOPERATIF}

Setiap siswa menyumbang pencapaian tujuan tersebut. Siswa yang bekerja dalam situasi pembelajaran kooperatif didorong untuk bekerjasama dalam menjalankan berbagai kegiatan belajar bersama-sama dan harus mengkoordinasikan usahanya untuk menyelesaikan tugas yang menjadi tanggungjawab siswa. Penerapan pada pembelajaran kooperatif, 4-5 siswa saling tergantung satu sama lain untuk mencapai suatu penghargaan bersama.

Menurut pandangan Muslimin Ibrahim, Fida Rachmadiarti, Muhammad Nur, et al (2000), unsur dasar pembelajaran kooperatif di antaranya adalah (1) siswa harus memiliki rasa kebersamaan dalam belajar dalam kelompoknya; (2) siswa bertanggung jawab terhadap segala sesuatu di dalam kelompoknya, ada rasa saling memiliki (sense of belonging); (3) siswa harus berpola pikir (mindset) bahwa semua anggota kelompoknya mempunyai tujuan yang sama; (4) siswa harus berbagi tugas dan tanggung jawab yang sama dalam kelompok; dan (5) kegiatan evaluasi baik secara individu maupun secara kelompok akan tetap diterapkan. Pemahaman yang ingin dicapai dari pola pembelajaran kooperatif adalah bahwa (1) siswa bekerja dalam kelompok secara kooperatif untuk menuntaskan materi belajarnya; (2) susunan anggota kelompok terdiri dari siswa yang berkemampuan 
tinggi, sedang dan rendah (heterogeneous cognitive skills); (3) setiap anggota kelompok tidak boleh membedakan suku, agama, dan ras; dan (4) penghargaan lebih bersifat kelompok daripada individu.

Menurut Rex, Murnen, Hobbs, et al. (2002) "the analyses of the teachers' object lesson stories illustrate the particular dispositions, beliefs, and values that they manifested for their own roles as teachers as well as for their students' roles as learners." Analisis pada cerita para guru mengenai pelajaran, menggambarkan fakta-fakta, keyakinankeyakinan, dan nialai-nilai tertentu yang mereka manifestasikan bagi perannya sebagai guru dan juga peran para siswa sebagai pelajar. Dalam proses pembelajaran, antara guru dan siswa harus saling menempatkan posisi sesuai dengan peran masingmasing. Terciptanya kondisi yang baik dan semestinya memungkinkan tumbuh berkembangnya kreativitas pada setiap siswa. Pembelajaran berdasarkan masalah tampaknya sangat efektif untuk mengajarkan proses berpikir tingkat tinggi (higher-order thinking skills) yang membantu siswa mengolah informasi yang telah dimiliki, dan membangun pengetahuan tentang dunia nyata di sekitarnya, di mana menurut Borich (2000) proses berpikir tingkat tinggi melibatkan analisis, sintesis, dan pembuatan keputusan yang dipercayai mampu memberikan stimulasi lebih melalui interaksi dengan para pembelajar lainnya dibandingkan hanya melalui buku-buku dan proses belajar klasikal yang cenderung tidak interaktif.

Model belajar diskusi ini, menurut Soeparman Kardi dan Muhammad Nur (2000), "terlepas dari pendekatan atau metode pembelajaran yang diterapkan oleh guru, pada saat-saat tertentu selama berlangsungnya proses belajar, diperlukan dialog antara guru dengan siswa dan siswa dengan siswa".
Dialog antara guru dengan siswa dan siswa dengan siswa inipun ditekankan kembali oleh Borich (2000), bahwa satu tujuan dari interaksi guru-siswa selama pembelajaran kooperatif berlangsung adalah mengedepankan gagasan atau pemikiran yang independen (independent thinking). Pembelajaran kooperatif memfokuskan bagaimana para siswa berpikir untuk kepentingan diri mereka, melalui independensi materi pembelajaran yang ada. Untuk mengakomodasi tujuan ini, seorang guru harus berperan dan berkolaborasi dengan siswa secara maksimal dalam waktu bersamaan dalam pembelajaran mandiri. Tujuan guru adalah membantu kelompok-kelompok menjadi lebih mampu merefleksikan diri dan peduli terhadap kinerja mereka, seraya interaksi antara siswa dalam kelompok pembelajaran kooperatif berjalan intensif dan berlangsung lama, di mana siswa terus bertanggungjawab terhadap materi pelajaran lainnya. Selama pembelajaran kooperatif, umpan balik, penguatan, dan dukungan datang dari rekan sejawat (student peers) dalam kelompok. Hubungan antara siswa mengutamakan keleluasaan waktu selama kegiatan pembelajaran kooperatif berlangsung. Kelompok dengan anggota 4-5 siswa bekerjasama dalam kedekatan hubungan fisik mengedepankan tugas-tugas rutin, melakukan kolaborasi, memberikan dukungan dan umpan balik dengan baik. Hal utama dalam pembelajaran kooperatif terkait dengan keingingan individu memfasilitasi tugas rekan sejawat.

Kunci keberhasilan kegiatan pembelajaran kooperatif menurut Borich tergantung pada komunikasi guru terhadap harapan-harapan, tanggungjawab dan cara memberikan peran kepada siswa ketika diperlukan. Hal ini sebagai alasan lain kenapa pembelajaran kooperatif memiliki sedikit 
kesamaan dengan model kelompok-kelompok diskusi yang dibentuk; tidak hanya sebagai seorang guru yang memutuskan jenis pekerjaan dan tugas-tugas khusus yang harus dilaksanakan oleh siswa, tetapi dia juga harus merancang metode yang mengadopsi cara penyelesaian tugas secara runtut. Esensi belajar kooperatif menurut Slavin (1990) adalah bagaimana metode dalam belajar kelompok, para siswa bekerja bersama dalam tim yang terdiri dari 4-5 anggota untuk menuntaskan materi yang awalnya disampaikan oleh guru.

Tabel 1. Dimensi Manajemen Pembelajaran Kooperatif

\begin{tabular}{|c|c|}
\hline Fungsi Manajemen & Pembelajaran Kooperatif \\
\hline - Perencanaan & $\begin{array}{l}\text { - Struktur tugas mengacu pada bagaimana pembelajaran kooperatif itu dijalankan } \\
\text { di satuan pendidikan dan jenis kegiatan yang dilakukan siswa di kelas. } \\
\text { - Struktur tujuan dengan hasil belajar akademis yang tinggi (kelompok atau } \\
\text { individu), pengembangan keterampilan sosial (menjadi pendengar yang baik, } \\
\text { pembicara yang baik, mau berbagi tugas, yang cerdas mau membantu yang lemah) } \\
\text { dan penerimaan terhadap keanekaragaman (suku, agama, dan kemampuan) } \\
\text { - Struktur penghargaan kooperatif dalam situasi pembelajaran kooperatif disikapi } \\
\text { sebagai wujud kerjasama pada suatu tugas bersama, dan siswa harus } \\
\text { mengkoordinasikan usahanya untuk menyelesaikan tugas tersebut. }\end{array}$ \\
\hline - Pengorganisasian & $\begin{array}{l}\text { - Waktu (membaca teks, berdiskusi, mengerjakan tugas, sehingga setiap kelompok } \\
\text { - Pecil dapat bekerja dalam kelompok masing-masing) } \\
\text { yang berbeda, ada kelompok asal, kelompok ahli, dan kelompok ahli mengajari } \\
\text { anggota kelompok asal } \\
\text { - Materi sesuai dengan pokok atau subpokok bahasan (menarik, bermanfaat, dan } \\
\text { sesuai tingkat berpikir siswa) } \\
\text { - Pembentukan kelompok belajar siswa (campuran etnik, agama, jenis kelamin, } \\
\text { - } \text { emampuan, dengan anggota antara 4-5 orang siswa) } \\
\text { - Pengembangan materi dan tujuan ada pada panduan belajar, materi menarik, } \\
\text { - Mda keterlibatatan tenaga teknis/laboran, dan pustakawan } \\
\text { - sengenalkan siswa kepada tugas dan peran dengan disediakan petunjuk khusus } \\
\text { - Jadwal dan tempat perlu dijelaskan, terkait dengan waktu kegiatan, tempat dan } \\
\text { format tempat duduk. }\end{array}$ \\
\hline - Aktivitas & $\begin{array}{l}\text { - Guru, membagi tugas dengan menyampaikan penjelasan umum berdemonstrasi, } \\
\text { memonitor, membantu siswa yang mendapat kesulitan dan mengevaluasi hasil } \\
\text { belajar. } \\
\text { - Siswa membaca materi tugas, berdiskusi dengan kelompok ahli, mengajari } \\
\text { anggota kelompok asal, mengerjakan tugas, menyajikan hasil tugas di depan } \\
\text { kelas. }\end{array}$ \\
\hline - Evaluasi & - Hasil tugas kelompok dan/atau individu, dan hasil berupa tes formatif dan sumatif \\
\hline
\end{tabular}


Menurut Soeparman Kardi dan Muhammad Nur (2000) dalam pembelajaran kooperatif, siswa dituntut cakap dalam bidang akademik, cakap dalam bidang sosial, dan dapat menerima keanekaragaman. Upaya untuk memperoleh kecakapan harus dilalui siswa dengan bekerja dalam suatu tim, seperti mendengarkan pendapat teman lainnya, merespon, menyetujui, tidak menyetujui, memperjelas, dan sebagainya. Kemampuan seperti ini perlu dimiliki oleh setiap anggota agar dapat bekerja sama secara produktif. Pembelajaran kooperatif dapat digunakan untuk mengajarkan materi yang lebih kompleks, dapat membantu guru untuk mencapai tujuan-tujuan yang berdimensi sosial dan hubungan sesama manusia. Pembelajaran kooperatif dikembangkan berdasarkan teori kognitif-konstruktivistik dan teori belajar sosial. Siswa harus mampu bekerja dalam tim, dan diminta bertanggung jawab secara individu terhadap materi yang dipelajari secara kelompok.
Pembelajaran kooperatif memberikan kesempatan bagi siswa dengan latar belakang yang heterogen, di mana kondisi kerja dalam kelompok pun saling bergantung satu dengan lainnya, yaitu melalui penghargaan secara kooperatif, belajar saling menghargai. Dapat disimpulkan bahwa dalam pembelajaran kooperatif ada beberapa hal penting atau keterampilan yang tetap terus dilatih dan dikembangkan, seperti bekerja dalam satu tim, menjadi pendengar atau pembicara yang baik, berbagi tugas, siswa yang pandai membantu siswa yang kurang pandai dan sebagainya. Selain diutamakan dalam membantu siswa memahami konsep yang kompleks, pembelajaran kooperatif pun berguna untuk membantu siswa menumbuhkan kemampuan kerjasama (Muslimin Ibrahim, Fida Rachmadiarti, Muhammad Nur, et al, 2000). Langkah-langkah pembelajaran kooperatif dapat dilakukan seperti terdapat pada tabel 2 .

Tabel 2. Langkah - Langkah Pembelajaran Kooperatif

\begin{tabular}{|c|c|}
\hline Tahap & Aktivitas Guru \\
\hline $\begin{array}{l}\text { 1. Menyampaikan tujuan dan } \\
\text { memotivasi siswa }\end{array}$ & $\begin{array}{l}\text { 1. Menyampaikan tujuan pembelajaran yang ingin dicapai } \\
\text { dan memotivasi siswa untuk belajar dengan baik dan } \\
\text { menyenangkan. }\end{array}$ \\
\hline 2. Menyampaikan informasi & $\begin{array}{l}\text { 2. Menyampaikan informasi dengan cara demonstrasi atau } \\
\text { memperagakan melalui materi pelajaran }\end{array}$ \\
\hline $\begin{array}{l}\text { 3. Membentuk kelompok-kelompok } \\
\text { kecil dalam belajar }\end{array}$ & $\begin{array}{l}\text { 3. Menjelaskan cara membentuk kelompok kecil (4-5 siswa) } \\
\text { belajar dan membantu siswa agar melakukan diskusi } \\
\text { secara tepat dan efektif }\end{array}$ \\
\hline 4. Membimbing belajar siswa & 4. Membimbing siswa ketika mengerjakan tugas pelajaran \\
\hline 5. Mengevaluasi proses pembelajaran & $\begin{array}{l}\text { 5. Mengevaluasi hasil belajar secara kelompok dan atau } \\
\text { secara individu secara berkelanjutan }\end{array}$ \\
\hline 6. Memberikan penghargaan siswa & $\begin{array}{l}\text { 6. Menyampaikan penghargaan secara kelompok dan atau } \\
\text { secara individu atas capaian hasil belajar mereka }\end{array}$ \\
\hline
\end{tabular}




\section{PENDEKATAN PEMBELAJARAN MODEL JIGSAW}

Mutu belajar dapat dipengaruhi oleh ketepatan pendekatan yang digunakan guru ketika mengajar. Sebagai contoh, pendekatan model ceramah biasanya monoton, tidak menarik, tidak memberdayakan siswa, dan membuat siswa cepat bosan. Pendekatan dengan ceramah hanya efektif untuk menyampaikan hal-hal yang bersifat umum, tidak efektif untuk melibatkan siswa dalam kegiatan belajar, memberikan pengalaman belajar, dan meningkatkan kualitas belajar. Dalam kegiatan belajar mengajar, terdapat partisipasi antara guru dan siswa, dalam membentuk pengetahuan, membuat makna, mencari kejelasan, bersikap kritis, dan mengadakan pembenaran. Terkait dengan hal tersebut, tentunya dapat juga dikatakan bahwa belajar sebagai cara membentuk seseorang berpikir secara benar dan membiarkan mereka berpikir secara mandiri.

Melalui metode belajar siswa aktif (student active learning), siswa terlibat secara langsung untuk mendapatkan makna dalam setiap kegiatan belajar. Penciptaan keadaan belajar yang demikian akan mendorong rasa ingin tahu siswa terhadap materi yang sedang dipelajari, baik secara individu maupun kelompok. Kondisi belajar yang dapat berlangsung secara aktif, menunjukkan bahwa siswa akan memiliki motivasi untuk mencapai suatu tujuan. Sehubungan dengan masalah mutu hasil belajar, perlu adanya pengorganisasian berbagai muatan, agar praktik dalam kehidupan sehari-hari lebih nyata dan dapat dirasakan hasilnya. Kegiatan belajar mengajar yang mengaitkan dengan kehidupan nyata, akan mendorong tumbuh kembangnya motivasi belajar siswa, karena secara langsung siswa merasakan manfaat dari apa yang telah mereka pelajari dan lakukan.
Selain menekankan pada penguasaan materi belajar, guru juga melatihkan keterampilan berkomunikasi dan proses berkelompok (social activities) dengan baik dalam melaksanakan proses pembelajaran kepada siswa. Dalam kegiatan belajarmengajar, kelas dibagi menjadi berkelompok dengan 4-5 siswa secara acak pada masing-masing kelompok. Kemudian langkah-langkah selanjutnya adalah seperti berikut: (1) siswa memilih topik yang wilayahnya telah ditetapkan oleh guru; (2) bersama guru, siswa merencanakan prosedur belajar kooperatif, tugas dan tujuan khusus yang akan dicapai sesuai dengan topik yang dipilih; (3) siswa melaksanakan kegiatan sesuai dengan rencana yang telah disepakati bersama, guru mengikuti secara ketat perkembangan dan kemajuan yang dicapai serta menawarkan bantuan bila diperlukan; (4) siswa melakukan analisis dan mengevaluasi informasi yang diperoleh, bagaimana informasi itu diringkas agar dapat disajikan di hadapan teman-temannya secara menarik; dan (5) beberapa dan atau semua kelompok menyajikan hasil pembelajarannya di hadapan kelas, dengan tujuan agar siswa lainnya ikut memperoleh perspektif luas, tentang jawaban setiap pertanyaan yang ada pada topik tersebut.

Johnson dan Johnson (1994; Muijs dan Reynolds, 2005) menyarankan bahwa sejumlah peran dapat diberikan kepada siswa dalam kelompok kecil, seperti (1) the summarizer, yaitu siswa yang bertugas mempersiapkan persiapan kelompok bagi kelasnya dan memberikan kesimpulan yang didapat, apakah anggota kelompok lainnya setuju atau tidak; (2) the researcher, yaitu siswa yang mengumpulkan informasi latar belakang dan mencari informasi tambahan yang diperlukan untuk menyelesaikan tugas; (3) the checker, yaitu siswa yang memeriksa bahwa fakta-fakta yang akan dipergunakan oleh 
kelompoknya benar dan siap mempertahankannya di hadapan guru dan kelompok lainnya; (4) the runner, yaitu siswa yang bertugas mencari referensi atau daftar pustaka yang diperlukan untuk melengkapi tugas, seperti peralatan dan kamus; (5) the observer atau troubleshooter, yaitu siswa yang mencatat dan merekam proses jalannya diskusi; dan (6) the recorder, yaitu siswa yang melakukan resume hasil diskusi kelompok dan mensintesiskan hasil diskusi dari anggota kelompok lainnya.

Memberikan nilai kepada individu siswa (siwa yang bekerja meraih tujuan kelompok) dan kepada kelompok (seluruh kelompok) sebagai sebuah strategi yang efektif untuk memastikan akuntabilitas bagi tujuan kelompok dan individu. Setelah menyelesaikan tugas kelompok, hasil diskusi perlu dipresentasikan di depan kelas dan sesi pendalaman memfokuskan pada proses tugas kelompok (efektivitas kolaborasi) yang harus dilakukan. Langkah awal yang bermanfaat dilakukan dengan melakukan sesi pendalaman dengan bertanya kepada siswa apakah hal yang telah mereka pikirkan berdampak baik ataukah buruk selama menyelesaikan tugas kelompok (seperti dijelaskan di atas oleh the observer). Kemudian guru dapat memberikan umpan balik terhadap berbagai elemen yang menurut dia sudah baik dan kurang baik, dan menanyakan kepada siswa bagaimana proses tersebut dapat ditingkatkan atau diperbaiki.

Menurut definisi yang dikemukakan oleh Instructional Strategies Online-Jigsaw (2005). Jigsaw is a cooperative learning strategy that enables each study of a "home" group to speciallisze in one aspect of a learning unit. Students meet with members from other groups who are assign the same aspect, and after mastering the material, return to the "home"group and teach the material to their group members. (Jigsaw sebagai strategi belajar kelompok yang mengharuskan masing-masing pembelajar pada grup "asal" mengkhususkan pada satu aspek unit belajar. Para siswa bertemu dengan anggota dari kelompok lain yang ditugasi aspek yang sama, dan sesudah menuntaskan materi, kembali ke grup "asal" dan mengajarkan materi ke anggota-anggota kelompoknya). Penerapan jigsaw, siswa berkelompok dengan anggota 4-5 siswa secara acak. Posisi duduk berhadapan seperti yang terlihat pada gambar 1 . Materi palajaran diberikan dalam bentuk teks. Setiap anggota kelompok bertanggungjawab untuk mempelajari bagian tertentu dari materi yang diberikan. Kelompok ini disebut kelompok asal atau kelompok rumah seperti yang disebutkan di atas.
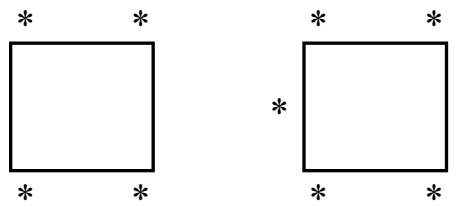

\section{Gambar 1. Posisi Anggota Kelompok dalam Belajar Kooperatif}

Anggota setiap kelompok yang memperoleh tugas dengan bagian yang sama, berkumpul membentuk kelompok baru, untuk mendiskusikan apa yang telah mereka pelajari. Kelompok ini disebut kelompok ahli, penjelasan di atas disebut juga kelompok rumah (homebase). Selanjutnya anggota kelompok ahli, kembali ke kelompok asal untuk mengajari anggota kelompoknya yang belum mempelajari apa yang telah mereka pelajari. Kalau digambarkan rangkaian kerja tim jigsaw seperti tampak pada gambar 2. Menyusul pertemuan dan diskusi kelompok asal, setiap anggota kelompok diberi kuis mengenai materi yang telah dipelajari. Belajar kooperatif model Slavin dengan prosedur penyekoran tim ini dimulai dari pembentukan 
kelompok, penerimaan kelompok, penerimaan tugas individu, diskusi pada kelompok asal sampai diberikan kuis untuk setiap individu, yang disebut satu siklus. Apabila pada siklus pertama, ternyata keterampilan dan kompetensi yang dituju belum diperoleh hasil yang maksimal, maka perlu dilakukan revisi program seperlunya, kemudian dilakukan proses belajar untuk siklus ke dua, demikian seterusnya sampai diperoleh hasil sesuai yang direncanakan.

\section{Kelompok Asal (Homebase Group)}

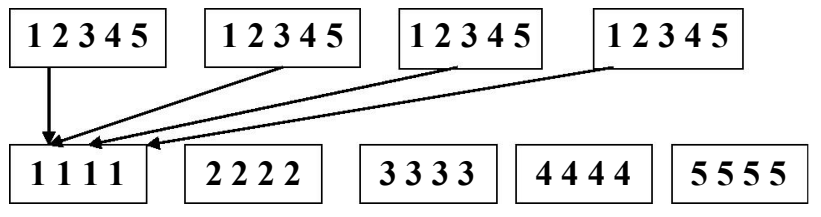

Kelompok Ahli (Expert Group)

Gambar 2.

Rangkaian Kerja Tim Jigsaw 1, 2, 3, 4, dan 5 = nama-nama anggota kelompok

Contoh materi pembelajaran kooperatif di bawah ini dapat diberikan melalui model jigsaw dengan tema "mempelajari sejarah Perang Dunia II". Tugas yang diberikan, dikemas ke dalam topik yang lebih detil atau dalam bentuk teka-teki. Masingmasing kelompok diberi tugas atau memilih sebuah teka-teki dan kemudian mulai menginvestigasi. Ketika tindakan investigasi selesai, para anggota kelompok melaporkan apa yang telah mereka pelajari dibantu dengan gambar yang lengkap terkait dengan masalah atau teka-teki yang ada. Contoh tema story telling untuk pelajaran Reading berikut ini dapat diberikan melalui pola pembelajaran kooperatif model jigsaw:
"Your thirty students are divided into five jigsaw groups with six students per group. The task is to learn about World War II. In every jigsaw group one person is responsible for researching Hitler 's rise to power, a second to fact-find about concentration camps, a third to find out Britain's engagement, a fourth to study Russia 's part, a fifth to uncover Japan's role, and the sixth to learn about the development and the use of atomic bomb. Thus, each jigsaw group member has counterpart members in other groups researching the same topic. For example, in group 1, Sara is responsible for looking into Hitler's rise, in group 2, the same assignment falls to Tyler and so on.

Sara learns all she can about Hitler's rise to power. Then, before reporting to her personal jigsaw group, she meets with her counterparts (including Tyler) from other jigsaw groups. These "experts on Hitler'share what they have learned and discuss how they will present their findings to their jigsaw group.

Eventually students return to their jigsaw group and present a well-organized report. Students are then tested on what they have learned about World War II form their fellow group members" (Cruickshank, Jenkins dan Metcalf, 2006).

Muslimin Ibrahim, Fida Rachmadiarti, Muhammad Nur, et al (2000) menyatakan lebih lanjut bahwa beberapa unsur dalam pembelajaran kooperatif di antaranya: (1) dalam kelompok siswa harus merasa seperjuangan dengan teman kelompok lainnya; (2) siswa bertanggungjawab atas segala sesuatu di dalam kelompok; (3) siswa harus melihat setiap anggota mempunyai tujuan yang sama; (4) siswa harus berbagi tugas dengan anggota yang lain; dan (5) setiap siswa akan diberi kuis untuk penilaian dan sebagainya. Dalam penetapan pembelajaran kooperatif, dua atau 
lebih individu akan saling bergantung untuk memperoleh nilai atau penghargaan bersama dan mereka akan berbagi penghargaan tersebut seandainya mereka berhasil sebagai anggota kelompok. Keberhasilan belajar kooperatif tampaknya juga dipengaruhi bagaimana ciri-ciri guru yang berhasil atau guru yang efektif dalam memfasilitasi pembelajaran kooperatif. Guru yang dipandang berhasil harus mempunyai rasa cinta dengan belajar dan menguasai bidang studi sepenuhnya yang menjadi tanggungjawab dengan tugasnya. Guru yang efektif adalah guru yang mampu memotivasi siswa-siswanya untuk bekerja tidak sekadar mencapai suatu prestasi akademik dan non-akademik yang baik dan seimbang, tetapi juga mampu menjadi anggota masyarakat yang penuh tanggungjawab dengan berperan serta aktif.

Secara ideal guru yang diharapkan adalah guru yang memiliki keberdayaaan untuk mampu mewujudkan kinerja yang dapat mewujudkan fungsi dan perannya seoptimal mungkin. Perwujudan tersebut tentunya akan dilihat dari kemampuan mereka dalam mengajar, kemampuan berkomunikasi dengan siswa, kualitas hubungan dengan sesama guru, hubungan dengan orang tua siswa dan sikap-sikap keterampilan lainnya. Guru dipandang efektif bila pribadi-pribadi atau individu-individu tersebut dapat membantu perkembangan hasil belajar akademik siswa dan membimbing menuju ke tujuan sosial, moral, dan etika yang penting (Muhammad Surya, 2000). Menurut Soeparman Kardi dan Muhammad Nur (2000), ada empat sifat-sifat guru efektif: (1) memiliki pribadi untuk mengembangkan hubungan kemanusiaan yang tulus dengan para siswa, orang tua, dan para koleganya; (2) mempunyai sikap positif terhadap ilmu pengetahuan, menguasai dasar-dasar tentang belajar mengajar dan ilmu yang akan diajarkan; (3) menguasai sejumlah keterampilan mengajar yang telah dikenal di dunia pendidikan untuk mendorong siswa terlibat dalam pembelajaran; dan (4) mampu memotivasi siswa untuk berpikir reflektif dan memecahkan masalah. Makna lain dari penjelasan tentang guru dengan sifat-sifat efektif ini adalah guru yang mampu mengoptimalkan sumber daya yang ada di lingkungan sekitarnya, selain guru juga harus mampu mengatur strategi belajar, membantu menghubungkan pengetahuan lama dan baru, dan memfasilitasi proses pembelajaran.

\section{PENUTUP}

Penyiapan dan pelaksanaan rencana pembelajaran kooperatif model jigsaw sudah saatnya diterapkan secara berkelanjutan guna memberikan dampak yang positif dan konstruktif bagi siswa, baik itu kemampuan secara akademik maupun nonakademik demi membangun sebuah kebersamaan dalam proses pembelajaran dan mengurangi porsi pola pembelajaran yang menggunakan pendekatan model kompetitif atau individual. Kemampuan berpikir kritis, argumentatif, dan pemecahan masalah diterapkan dalam pembelajaran kooperatif yang melibatkan siswa lainnya. Pola pembelajaran kooperatif mengedepankan tujuan kepada para pesertanya memiliki komitmen dalam proses pembelajaran dan membudayakan pola-pola berpikir dan berperilaku tingkat tinggi. Kegiatan pembelajaran kooperatif dapat diterapkan secara bertahap dan berkelanjutan melalui berbagai aspek yang menjadi titik perhatian, seperti: akademik, sikap dan normanorma yang membimbing perilaku siswa di luar kelas menjadi lebih baik, menerima bentuk-bentuk etika atau nilai-nilai sosial yang dapat diterapkan di rumah, memiliki pandangan dan telaah secara objektif, mampu mereduksi gagasan dan perilaku yang kontradiktif dan ekstrim melalui kepribadian yang 
mantap, serta belajar menggunakan pola pikir tingkat tinggi.

Pembelajaran kooperatif dapat dimaknai menjadi sebuah pembelajaran yang berhasil dan bermanfaat bagi siswa apabila tercipta hubungan yang sinergis antara guru-siswa dan siswa-siswa. Dalam pembelajaran kooperatif model jigsaw ini, peran guru dapat dimaksimalkan dengan melakukan observasi pada masing-masing kelompok (4-5 siswa) agar tetap pada jalur belajar yang benar dan berkontribusi positif pada aspek emosional dan motivasi. Peran guru dalam kegiatan pembelajaran kooperatif sebagai fasilitator dan pembimbing menjadi penting di antara kelompokkelompok belajar, baik di dalam maupun di luar kelas. Adanya interaksi yang konstruktif antara siswa satu dengan yang lainnya menjadi indikator penting dalam membangun kebersamaan, memahami materi pembelajaran yang diberikan secara komprehensif, dan menyikapi perbedaan latar belakang rekan satu kelompok. Peran gurupun dalam model pembelajaran ini tidak boleh dominan (one-man show) dan menguasai kondisi pembelajaran, hal ini perlu diperhatikan guru untuk memberikan kesempatan dan keberanian kepada siswa mengemukakan pendapat atau gagasannya tanpa rasa ragu dan atau takut. Guru dapat mengawali proses pembelajaran dengan memberikan semangat kepada para siswa dengan mengatakan we work together or we fail together atau all for one and one for all. Maksud guru memberikan motivasi dengan ungkapan ini adalah untuk mengingatkan kepada para siswa agar melaksanakan kolaborasi dan bukan kompetisi dalam pembelajaran kooperatif model jigsaw.

\section{DAFTAR PUSTAKA}

Babbage. R., Byers, R., \& Redding, H. (2000). Approaches to Teaching and Learning. London: David Fulton Publishers.

Borich, G. D. (2000). Effective Teaching Methods (4th ed.). New Jersey: Prentice-Hall, Inc.

Cecep E. Rustana. (Januari 2001). Pendekatan Konstruktivis dalam Proses Pembelajaran IPA: Kebutuhan Pengembangan Akademik Dosen PGPLB FIP UNESA. Media Pendidikan dan Ilmu Pengetahuan. Vol. 24, No. 8, 228-235.

Cony R. Semiawan, Putrawan, M \& Setiawan. (1988). Dimensi Kreatif dalam Filsafat Ilmu. Bandung: Remaja Rosda Karya.

Cruickshank, D. R., Jenkins, D. B., \& Metcalf, K. K. (2006). The Act of Teaching ( $4^{\text {th }}$ ed.). New York: The McGraw-Hill Companies, Inc.

Dede Rosyada. (2007). Paradigma Pendidikan

Demokratis: Sebuah Model Pelibatan Masyarakat dalam Penyelenggaraan Pendidikan. Jakarta: Kencana Prenada Media Group.

Depdiknas. (2003). Undang-Undang RI Nomor 20, Tahun 2003, Tentang Sistem Pendidikan Nasional.

Elias, J. L. \& Freire, P. (1994). Pedagogue of Liberation. Florida: Krieger Publishing Company

Instructional Strategies Online-Jigsaw. Diambil pada tanggal 15 September 2010, dari http:// olc.spsd.sk.ca/DE/PD/instr/strats/jigsaw/ 
Kauchak, D. P \& Eggen, P. D. (1998). Learning and Teaching, Research Based Methods. Boston: Allyn and Bacon.

Klein, S. B. (2002). Learning Principle and Applications (4 ${ }^{\text {th }}$ ed.). New York: $\quad$ McGraw Hill.

Mosston, M. (1972). Teaching from Command to Discovery. California: Wadsworth Publushing Company.

Muhammad Surya. (Januari 2000). Aspirasi Peningkatan Kemampuan Profesional dan Kesejahteraan Guru. Jurnal Pendidikan dan Kebudayaan, Tahun ke-5, No. 021, 1-5.

Muijs, D \& Reynolds, D. (2005). Effective Teaching: Evidence and Practice (2 ${ }^{\text {nd }}$ ed.). London: SAGE Publications Inc.

Muslimin Ibrahim, Fida Rachmadiarti, Muhammad Nur, et al. (2000). Pembelajaran Kooperatif. Surabaya: University Press.

Nurhadi. (2002). Pendekatan Kontekstual (Contextual Teaching and Learning). Jakarta: Direktorat Pendidikan Lanjutan Pertama, Direktorat Jenderal Pendidikan Dasar dan Menengah, Departemen Pendidikan Nasional.

Pannen, P, Dina Mustofa \& Mestika Sekarwinahyu. (2001). Konstruktivis dalam Pembelajaran. Jakarta: Proyek Pengembangan Universitas Terbuka Direktorat Jenderal Pendidikan Tinggi Departemen Pendidikan Nasional.
Ratumanan, T. G. (Januari 2003). Implikasi Teori Vygotsky dalam Pembelajaran Matematika. Media Pendidikan dan Ilmu Pengetahuan. Vol. 26, No.1, 34-44.

Reiger, R. C \& Stang, J. (2000). Management and Motivation: An Analysis of Productivity in Education and the Workplace. Diambil pada tanggal 17 Oktober 2010, dari http:// web2.info.rac.galegroup.com/itw/informark/2/

Rex, L. A, Murnen, T. J, Hobbs, J, et al. (2002). Teachers Pedagogical Stories and the Shaping of Classroom Participation: "The Dancer" and "Graveyard Ship at the 7-11." American Educational Research Journal, Volume 39, Number 39, 765-766.

Slavin, R. E. (1997). Educational Psychology: Theory and Practice ( $1^{\text {st }}$ ed.). Boston: Allyn and Bacon.

Soeparman Kardi \& Muhammad Nur. (2000). Pengantar pada Pengajaran dan Pengelolaan Kelas. Surabaya: University Press.

Sumadi Suryabrata. (1989). Psikologi Pendidikan. Jakarta: CV Rajawali. 